\title{
Forest vegetation management under debate: an introduction
}

\author{
Christian Ammer • Philippe Balandier • \\ Niclas Scott Bentsen • Lluís Coll • Magnus Löf
}

Published online: 20 November 2010

(c) The Author(s) 2010. This article is published with open access at Springerlink.com

The management of vegetation competition in forests ${ }^{1}$ is an integral part of silvicultural practices in many parts of the world (Wagner et al. 2006; Richardson et al. 2006; Newton 2006). However, there are substantial differences between the continents with regard to the preferred methods. The implementation of tending measures to control woody competitors is common in European even-aged stands as in other parts of the world. In contrast, the use of herbicides for weed control is much less common in Europe than for example in North America, South Africa, Australia and New Zealand where chemical vegetation control, in

This article originates from the final conference of the Cost action E47 "European Network for Forest Vegetation Management: Towards Environmental Sustainability" in Vejle, Denmark, 4-7 May 2009.

\section{Ammer $(\square)$}

Department of Silviculture and Forest Ecology of the Temperate

Zones, Georg-August-Universität, Göttingen, Germany

e-mail: Christian.Ammer@forst.uni-goettingen.de

P. Balandier

Cemagref, Research Unit on Forest Ecosystems,

Nogent-sur-Vernisson, France

P. Balandier

INRA, UMR547 PIAF, Clermont-Ferrand, France

\section{N. S. Bentsen}

Centre for Forest, Landscape and Planning,

University of Copenhagen, Frederiksberg, Denmark

L. Coll

Forest Functioning and Dynamics, Solsona Centre Tecnològic Forestal de Catalunya (CTFC), Solsona, Spain

\section{Löf}

Department Southern Swedish Forest Research Centre,

Swedish University of Agricultural Sciences, Alnarp, Sweden particular, is used and promoted strongly in plantation forestry (Newton 2006). If at all, in Europe, herbaceous vegetation is controlled predominantly by mechanical site preparation, mulching or other techniques (McCarthy et al. 2010, this issue). An overwhelming amount of literature has shown that chemical vegetation control can result in huge gains in wood volume (Wagner et al. 2006). This had let to favourable reports of chemical vegetation control as the following statements may indicate: 'in most instances, forests cannot be managed economically without herbicides if the goal is to grow seedlings at the potential of the site and the plant community includes sprouting hardwoods and shrubs of rhizomatous forbs and ferns' (McDonald and Fiddler 1993); 'most regeneration efforts around the world would fail or be severely delayed without effective forest vegetation management ... primarily using herbicides' (Wagner et al. 2006); 'reducing competition for desirable trees with modern chemicals has less impact on soil and wildlife habitat and lowers human health risk per unit of effectiveness than mechanical or manual methods' (Newton 2006). In contrast, in Europe at present there is political consensus for a reduction in the use of herbicides as much as possible (i.e. The EU Thematic strategy on the Sustainable Use of Pesticides). Society perceives European forests as the last quasi-natural compartments of a landscape which has been entirely manipulated for more than 2,000 years. In this context, herbicides are view by the public as a serious threat for the maintenance of the set of multiple functions that forests provide (Merlo and Croitoru 2005; Schmithüsen 2007; Ammer and Puettmann 2009).

\footnotetext{
${ }^{1}$ Forest vegetation management (FVM) is here defined according to Wagner et al. (2006) as follows: treatments directed at reducing competition for site resources (light, nutrients, water) between desired trees and associated plants or the cultivation of non-crop species to suppress unwanted species.
} 
Even those private woodland owners or public forest enterprises who focus on economically optimised timber production are directed towards alternatives to herbicides by forest certification schemes (in Europe as in other parts of the world, see Richardson et al. 2006). Besides the low social acceptability of herbicides (particularly in Central and Northern Europe), the role of chemical vegetation management in Europe may be limited for other reasons:

- As Balandier et al. (2006) pointed out in a review on forest vegetation management strategies, the competitiveness of different plant species groups such as graminoids, forbs, small shrubs, tall shrub or, canopy species differs considerably. The number of species within a group and their competitiveness is a result of the earth's glacial and postglacial geological and climatic history. Consequently this differs between and within geographic regions. Therefore, it may be that the diversity of competition, particularly from shrubs, is not as severe, at least in Central European forests, as in other parts of the world.

- Some major Central and Northern European tree species, such as Norway spruce (Picea abies (L.) Karst.), are very tolerant to interference by herbs and grasses, yet respond to weed control by a substantial increase in growth. However, non-chemical methods of vegetation control such as mechanical site preparation have sometimes proven to be as effective as repeated herbicide treatments (Nilsson and Örlander 1999). Woody competition between Norway spruce and birch (Betula pendula Roth), for instance, may even lead to niche complementarity between the two naturally coexisting functional groups, resulting in a higher total yield of the mixed stand compared to a pure Norway spruce or birch stand (Frivold and Frank 2002).

- Shelterwood and group selection management systems are common silvicultural tools which prescribe a considerable retention time of overstorey trees. When the overstorey species cast deep shade, such as European beech (Fagus sylvatica L.), competing vegetation may be very effectively suppressed. As the growth impact of a given level of competing vegetation on tree seedlings differs with species contributing to total cover (Maguire et al. 2009), already the weakening of light-demanding and highly competitive species by shading reduces competition.

- Most studies on chemical vegetation control have focused on the differences in growth and yield between managed and control stands, but very few have undertaken an economic evaluation of the treatments in long-term studies.

There are many European studies on forest vegetation management. These studies can be grouped in three main topics: (1) the response of target tree species to woody and herbaceous vegetation competition (e.g. Fotelli et al. 2001; Coll et al. 2004; Bloor et al. 2008); (2) the analysis of the effectiveness of various vegetation management techniques (e.g. Nilsson and Örlander 1999; Hytönen and Jylhä 2005; Balandier et al. 2006; Johansson et al. 2006; Jylhä and Hytönen 2006; Willoughby and Jinks 2009), and (3) the dynamics of forest ground vegetation and diversity under different forest management systems (e.g. Khanina et al. 2007; Heinrichs and Schmidt 2009). In contrast, in Europe the long-term effects of herbicides on fauna, microorganisms, other forest inhabitants and seepage water quality have not been studied in detail. However, the vast majority of studies on the use, and efficiency, of herbicides to control forest vegetation and improve the growth of crop trees have been conducted in North America under various environmental conditions.

Despite the large body of literature on FVM, the picture is far from clear. For example there are still:

- Inconsistent findings on the permanency of gains in growth and yield from FVM. The results from Wagner and Robinson's (2006) study indicate that vegetation control during the first few years after planting results in a substantially increased productivity of young conifer stands (Pinus banksiana, Pinus resinosa, Pinus strobes, Picea mariana) for the first decade. However, early height gains by Pinus taeda after herbaceous vegetation control treatments were not necessarily maintained throughout later stages of stand development. Quicke et al. (1999) assume that 'at some point volumes of all treatments are expected to level off and possibly decline because of mortality induced by intraspecific competition. It might also be that yields of untreated plots will catch up to plots with vegetation control as competition from herbaceous weeds diminishes'. This view is supported by Zhang et al. (2006) who investigated the effects of stand density and shrub competition on growth and development of Pinus ponderosa over a period of 35 years. They found that the timing of convergence of treated and untreated plots depends on stand density and site quality. An untreated dense stand on a productive site tends to converge towards the growth curve of a treated stand quite soon after planting. Maguire et al. (2009) also found a declining negative impact of competing vegetation on seedling growth with increasing tree size. In particular, the effect of herbaceous vegetation control seems to diminish over time. Examining the growth response of Pseudotsuga menziesii to different treatments of vegetation, Rose et al. (2006) found no growth differences between woody-only and herbaceous-only control treatments after 12 years, even though, just 3 years after planting, 
stem volume in the herbaceous control treatment had been more than $200 \%$ greater than in the woody-only control treatment.

- Inconsistent findings on the effect of overstorey density and gap size. Harrington (2006) found that overstorey density and vegetation control had additive effects on Pseudotsuga menziesii seedling responses and did not interact. However, in a previous study, Groot (1999) observed interactions between overstorey treatment (clearcut versus shelterwood) and vegetation control. Interestingly, in this study, Picea glauca seedlings responded to vegetation control on clearcuts by increasing seedling diameter but not height, whereas in shelterwood treatments, vegetation control increased both diameter and height growth. Gasser et al. (2010) investigated the effect of vegetation control, liming and gap size on the growth Acer saccharum and Betula alleghaniensis. They concluded that, although vegetation control had a significant effect on light and nutrient availability, particularly in large gaps, and resulted in some gain in growth, the high survival rates meant vegetation control was not warranted.

- Inconsistent results on the effects of ground vegetation control on foliar nutrient concentration. For Pinus taeda, Zutter et al. (1999) reported positive effects on foliar nutrient concentration and content at age two, but this effect diminished with time. In a study by Miller et al. (2006), intensive herbaceous plant control treatments were associated with decreases in soil $\mathrm{C}$ and $\mathrm{N}$ and reduced Pinus taeda foliage $\mathrm{N}$ and $\mathrm{K}$ at year 15 after FVM.

- Opposite effects of woody and herbaceous vegetation management. For example, control of woody competitors has been shown to increase herbaceous competition (Glover and Quicke 1999). The control of herbaceous species but not woody species resulted in much better seedlings growth than both herbaceousand woody-species control (Pitt et al. 2009).

- Inconsistent findings on the effect of chemical vegetation control on species richness. Balandier et al. (2006) have carefully reviewed the literature on the effect of herbicides on plant species richness. They reported that the 'vegetation composition can be partially or completely different from the initial one, but alternatively can also be more competitive than the initial vegetation'. In most cases, it is therefore necessary to continue herbicide application for several years.

In conclusion, it can be stated that the effect of FVM varies with regard to competitiveness and density of target species and weeds, site, stand age, functional group of the competitors and resource availability. This makes generalisations difficult, and underlines the need for future research to attempt to untangle the multiple factors and their potential interactions. Designing vegetation management experiments requires approaches that enable the study of the development of both competing species and target species over at least a decade (Balandier et al. 2006).

In view of the limited and scattered knowledge on the effects of FVM in Europe, the COST action E47, European Network for Forest Vegetation Management was initiated in 2005. In May 2009 a final international conference was held in Vejle Denmark. This special issue presents selected papers from this conference and highlights different aspects of FVM. The state of forest vegetation management in Europe is summarised by McCarthy et al. (2010, this issue) reflecting the different approaches by countries and geographical regions. Another review focuses on canopy effects on understorey vegetation (Wagner et al. 2010, this issue). As mentioned above, in Europe, overstorey canopies are widely used to favour tree regeneration over aggressive shade-tolerant graminoids and forbs. This approach of controlling understorey shrub vegetation by managing canopy cover was also the impetus for an investigation on plant species richness and natural tree regeneration in three post-storm sites in France (Dodet et al. 2010, this issue) and in Mediterranean forests in Spain (Coll et al. 2010, this issue). In the latter study a marked effect of tree layer composition and environment on the relationship between the development of understorey and overstorey tree structure was observed. Another study from southern Europe is presented by Prévosto et al. (2010, this issue). The goal of this study was to develop management strategies favouring the establishment and survival of two oak species in mature Allepo pine forests. Based on a controlled experiment in a nursery, Gaudio et al. (2010, this issue) examined the interaction between crop seedlings, density of three competing shrub species and available light. When shrub density increased, pine seedling growth was negatively affected because of reduced light availability. One of the few European longterm studies on the effect of post-planting weed control on the cover and composition of ground vegetation and on the growth, survival and nutrient concentrations of bare-rooted Scots pine seedlings was carried out by Hytönen and Jylhä (2010, this issue) in Finland over a 15-year period. They found the more intensive the weed control, the better the tree seedling growth and survival. In another study from Finland, the efficiency of three different methods for restricting European aspen (Populus tremula) sprouting was investigated (Hamberg et al. 2010, this issue). The results indicated that fungus treatment can restrict the emergence and growth of stump sprouts better than other methods. As very little is known about the competitive effects of invasive plant species on seedling growth, Ammer et al. (2010, this issue) tested the effect of different 
weed treatments for Himalayan balsam (Impatiens glandulifera) on survival and growth of Picea abies and Abies alba seedlings. It was shown that Himalayan balsam does not substantially restrict the growth of these tree species. However, its effect on seedling establishment was not tested. Although the debate about the need to use herbicides seems to be more prevalent in Europe than in other parts of the world, Thiffault and Roy (2010, this issue) review the historical context of the decision to ban herbicide use on Crown forested land in Québec, Canada, and the research conducted subsequent to this decision. This example illustrates that the discussion about FVM, its intensity, and, most important, appropriate methods is unresolved for many people throughout the world. In this situation, objective scientific research is more necessary than ever.

Acknowledgments We are grateful to Helen Desmond for linguistic corrections.

Open Access This article is distributed under the terms of the Creative Commons Attribution Noncommercial License which permits any noncommercial use, distribution, and reproduction in any medium, provided the original author(s) and source are credited.

\section{References}

Ammer C, Puettmann KJ (2009) Waldbau, quo vadis?Waldbewirtschaftung zwischen Funktionenorientierung und Multifunktionalität. Forstarchiv 80:90-96

Ammer C, Schall P, Wördehoff R, Lamatsch K, Bachmann M (2010) Does tree seedling growth and survival require weeding of Himalayan balsam (Impatiens glandulifera). Eur J For Res. doi: 10.1007/s10342-010-0413-0

Balandier P, Collet C, Miller JH, Reynolds PE, Zedaker SM (2006) Designing forest vegetation management strategies based on the mechanisms and dynamics of crop tree competition by neighbouring vegetation. Forestry 79:3-27

Bloor JMG, Leadley PW, Barthes L (2008) Responses of Fraxinus excelsior seedlings to grass-induced above- and below-ground competition. Plant Ecol 194:293-304

Coll L, Balandier P, Picon-Cochard C (2004) Morphological and physiological responses of beech (Fagus sylvatica L.) seedlings to grass-induced belowground competition. Tree Physiol 24: $45-54$

Coll L, González-Olabarria J R, Mola-Yudego B, Pukkala T, Messier C (2010) Predicting understory maximum shrubs cover using altitude and overstory basal area in different Mediterranean forest. Eur J For Res. doi:10.1007/s10342-010-0395-y

Dodet M, Collet C, Frochot H, Wehrlen L (2010) Tree regeneration and plant species diversity responses to vegetation control following a major windthrow in mixed broadleaved stands. Eur $\mathrm{J}$ For Res. doi:10.1007/s10342-010-0406-Z

Fotelli MN, Geßler A, Peuke AD, Rennenberg H (2001) Drought affects the competitive interactions between Fagus sylvatica seedlings and an early successional species, Rubus fruticosus: responses of growth, water status and delta $\mathrm{C}-13$ composition. New Phytol 151:427-435
Frivold LH, Frank J (2002) Growth of mixed birch-coniferous stands in relations to pure coniferous stands at similar sites in southeastern Norway. Scand J For Res 17:139-149

Gasser D, Messier C, Beaudet M, Lechowicz MJ (2010) Sugar maple and yellow birch regeneration in response to canopy opening, liming and vegetation control in a temperate deciduous forest of Quebec. For Ecol Manag 259:2006-2014

Gaudio N, Balandier P, Gwenaël P, Dumas Y, Jean F, Ginisty C (2010) Light-mediated influence of three understorey species (Calluna vulgaris, Pteridium aquilinum, Molinia caerulea) on the growth of Pinus sylvestris seedlings. Eur J For Res. doi:10.1007/s10342010-0403-2

Glover G, Quicke H (1999) Growth response of loblolly pine, sweetgum, and water oak in a pine-hardwood density study. Can J For Res 29:968-978

Groot A (1999) Effects of shelter and competition on the early growth of planted white spruce (Picea glauca). Can J For Res 29: 1002-1014

Hamberg L, Malmivaara-Lämsä M, Löfström I, Vartiamäki H, Valkonen S, Hantula J (2010) Sprouting of Populus tremula L. in spruce regeneration areas following alternative treatments. Eur J For Res. doi:10.1007/s10342-010-0372-5

Harrington TB (2006) Five-year growth responses of Douglas-fir, western hemlock, and western redcedar seedlings to manipulated levels of overstory and understory competition. Can J For Res 36:2439-2453

Heinrichs S, Schmidt W (2009) Short-term effects of selection and clear cutting on the shrub and herb layer vegetation during the conversion of even-aged Norway spruce stands into mixed stands. For Ecol Manag 258:667-678

Hytönen J, Jylhä P (2005) Effects of competing vegetation and postplanting weed control on the mortality, growth and vole damages to Betula pendula planted on former agricultural land. Silva Fennica 39:365-380

Hytönen J, Jylhä P (2010) Long-term response of weed control intensity on Scots pine on survival, growth and nutrition on former arable land. Eur J For Res. doi:10.1007/s10342-0100371-6

Johansson K, Örlander G, Nilsson U (2006) Effects of mulching and insecticides on establishment and growth of Norway spruce. Can J For Res 36:2377-2385

Jylhä P, Hytönen J (2006) Effect of vegetation control on the survival and growth of Scots pine and Norway spruce planted on former agricultural land. Can J For Res 36:2400-2411

Khanina L, Bobrovsky M, Komarov A, Mikhajlov A (2007) Modeling dynamics of forest ground vegetation diversity under different forest management regimes. For Ecol Manag 248:80-94

Maguire DA, Mainwaring DB, Rose R, Garber SM, Dinger EJ (2009) Response of coastal Douglas-fir and competing vegetation to repeated and delayed weed control treatments during early plantation development. Can J For Res 39:1208-1219

McCarthy N, Bentsen NS, Willoughby I, Balandier P (2010) The state of forest vegetation management in Europe in the 21st century. Eur J For Res. doi:10.1007/s10342-010-0429-5

McDonald PM, Fiddler GO (1993) Feasibility of alternatives to herbicides in young conifer plantations in California. Can J For Res 23:2015-2022

Merlo M, Croitoru L (eds) (2005) Valuing Mediterranean forests: towards total economic value. CABI Publishing, Wallingford, p 406

Miller JH, Allen HL, Zutter BR, Zedaker SM, Newbold RA (2006) Soil and pine foliage nutrient responses 15 years after competing-vegetation control and their correlation with growth for 13 loblolly pine plantations in the southern United States. Can J For Res 36:2412-2425 
Newton M (2006) Taking charge in forest vegetation management. Can J For Res 36:2357-2363

Nilsson U, Örlander G (1999) Vegetation management on grassdominated clearcuts planted with Norway spruce in southern Sweden. Can J For Res 29:1015-1026

Pitt DG, Morneault A, Parker WC, Stinson A, Lanteigne L (2009) The effects of herbaceous and woody competition on planted white pine in a clearcut site. For Ecol Manag 257:1281-1291

Prévosto B, Monnier Y, Ripert C, Fernandez C (2010) Diversification of Pinus halepensis forests by sowing Quercus ilex and Quercus pubescens acorns: testing the effects of different vegetation and soil treatments. Eur J For Res. doi:10.1007/s10342-010-0396-x

Quicke H, Glover G, Glover R (1999) Loblolly pine growth response to herbaceous vegetation control at different planting densities. Can J For Res 29:960-967

Richardson B, Watt MS, Mason EG, Kriticos DJ (2006) Advances in modelling and decision support systems for vegetation management in young forest plantations. Forestry 79:29-42

Rose R, Rosner LS, Ketchum JS (2006) Twelfth-year response of Douglas-fir to area of weed control and herbaceous versus woody weed control treatments. Can J For Res 36:2464-2473

Schmithüsen F (2007) Multifunctional forestry practices as a land use strategy to meet increasing private and public demands in modern societies. J For Sci 53:290-298
Thiffault N, Roy V (2010) Living without herbicides in Québec (Canada): historical context, current strategy, research and challenges in forest vegetation management. Eur J For Res. doi:10.1007/s10342-010-0373-4

Wagner RG, Robinson AP (2006a) Critical period of interspecific competition for four northern conifers: 10-year growth response and associated vegetation dynamics. Can J For Res 36:2474-2485

Wagner RG, Little KM, Richardson B, McNabb K (2006b) The role of vegetation management for enhancing productivity of the world's forests. Forestry 79:57-79

Wagner S, Fischer H, Huth F (2010) Canopy effects on vegetation caused by harvesting and regeneration treatments. Eur J For Res. doi:10.1007/s10342-010-0378-z

Willoughby I, Jinks RL (2009) The effect of duration of vegetation management on broadleaved woodland creation by direct seeding. Forestry 82:343-359

Zhang JW, Oliver WW, Busse MD (2006) Growth and development of ponderosa pine on sites of contrasting productivities: relative importance of stand density and shrub competition effects. Can J For Res 36:2426-2438

Zutter BR, Miller JH, Allen HL, Zedaker SM, Edwards MB, Newbold RA (1999) Fascicle nutrient and biomass responses of young Loblolly pine to control of woody and herbaceous competitors. Can J For Res 29:917-925 